\title{
Undergraduate Certificate in Beef Cattle Production Management
}

\section{DOI:10.31274/air.13020}

Jennifer M. Bundy, Assistant Professor; Elisabeth Huff-Lonergan, Professor; Jodi A. Sterle, Professor; Joan E. Cunnick, Professor;

Christen G. Burgett, Associate Teaching Professor; Laura L. Greiner, Assistant Professor; Elizabeth A. Bobeck, Assistant Professor; Nicholas K. Gabler, Professor; Steven M. Lonergan, Morrill Professor; Department of Animal Science, Iowa State University

\section{Summary and Implications}

Iowa State University (ISU) offers undergraduate certificates to demonstrate completion of a focused study in a specialized area across a variety of disciplines. The certificate has the significant benefit of allowing students to customize their curriculum and document completion of an approved course of study. A Beef Cattle Production Management Certificate is offered within the Animal Science Department at ISU. The certificate requirements are organized to correspond with faculty and employer-defined needs for a successful transition from ISU student to beef cattle industry professional.

The Beef Cattle Production Management certificate will integrate technical topics in animal science with practical considerations in enterprise management. Two critical components to the certificate are the capstone Beef Cattle Enterprise Management course and a required internship that focuses on beef cattle management. Students that complete the certificate will have the background to identify and address challenges in modern beef cattle production enterprises. Further, the certificate assists employers in identifying students that have shown the interest, discipline, and ability to complete this specialized study program.

\section{Introduction}

The beef industry is vital to the economy in the USA and Iowa. In 2016, Iowa's beef industry generated an estimated $\$ 6.30$ billion of economic activity in the state of Iowa alone. Of this direct effect, cattle production accounted for $\$ 3.86$ billion. An estimated $\$ 2.21$ billion in economic activity comes from indirect and induced effects. Iowa's beef industry supported an estimated 32,317 jobs in 2016. Of this, the industry directly employed 19,528 people.
Beef cattle production is a diverse enterprise that requires expertise in cattle growth and development, endocrinology, reproductive management, nutrition, and cattle evaluation. Enterprise management is also a vital component of a successful program. Responsible and efficient management of beef production contributes to the environmental services and production of high-quality human food. The United States is a net exporter of beef products (based on value), and therefore successful management contributes to a growing agriculture economy. The demand for professionals with expertise in beef cattle production management is rising and is acutely evident. Expertise is necessary for traditional production venues and expands to environmental quality, food safety, and sustainability. Students need a clear path to customize and document their training and expertise in this area. Documentation of the certificate on the transcript provides a way for students to show how they pursued and completed a customized course of study and have achieved competency in beef cattle production management.

\section{Approach}

The objective was to develop a beef cattle production management course of study within the requirements of an undergraduate certificate. Students that complete the certificate will be able to:

a. Demonstrate a breadth of understanding of nutrition, physiology, and breeding applications in contemporary beef cattle production systems.

b. Evaluate production systems and provide solutions to ensure the efficient production of safe, high-quality beef.

c. Recognize issues that affect the utilization of natural resources in beef cattle production systems.

d. Demonstrate competence in hands-on and practical applications in their field.

e. Apply managerial skills in the context of a beef cattle production system.

f. Demonstrate the development of the knowledge, skills, and abilities necessary for a beef cattle production management career.

\section{Requirements of the Beef Production Management Certificate}

The Beef Cattle Production Management Certificate program prompts students to customize their certificate with specific scientific disciplines and production practices. This 24-credit certificate provides the appropriate background and

Copyright (C) 2021 by the Authors. This is an open access article published under the CC BY-NC license (https://creativecommons.org/licenses/by-nc/4.0/), which allows for non-commercial reuse with proper attribution. 
context for developing their beef cattle production and management expertise.

The certificate requirements are organized to correspond with faculty and employer-defined needs for a successful transition from ISU student to beef cattle industry professional. Successful completion of the certificate requires a minimum of 18 credits at the 300 (junior) or 400 (senior) level. The program integrates beef cattle production principles with foundation disciplines in animal science. All courses in the certificate are available, and full descriptions are available in the Iowa State University Catalog (https://catalog.iastate.edu).

The certificate requires completion of courses within the following categories: Foundation ( 3 credits), Fundamental Disciplines ( 9 credits), Expertise Expansion (3 credits from a menu), Management ( 3 credits from a menu), and Beef Cattle Production Emphasis (6 credits). Per ISU policy, nine credits will be unique to the certificate and will not be applied to a major, minor, or another certificate.

\section{Availability of the Beef Cattle Production and Management Certificate}

The Beef Cattle Production Management Certificate has been approved by the Department of Animal Science Curriculum Committee, the College of Agriculture and Life Sciences College Curriculum committee, and the Faculty Senate. Therefore, the Beef Cattle Production Management Certificate will be available to ISU undergraduate students beginning in the fall of 2021.

\section{Beef Cattle Production Management Certificate} (24 CREDITS)

\begin{tabular}{|c|c|c|}
\hline \multicolumn{2}{|c|}{ Foundation Course (3 credits) } & \multirow{2}{*}{$\begin{array}{r}\text { Credits } \\
3\end{array}$} \\
\hline AN S 226 & Beef Science & \\
\hline \multicolumn{3}{|c|}{ Fundamental Disciplines (9 credits) } \\
\hline AN S 320 & $\begin{array}{l}\text { Animal Feeds and } \\
\text { Feeding }\end{array}$ & 3 \\
\hline AN S 331 & $\begin{array}{l}\text { Domestic Animal } \\
\text { Reproduction }\end{array}$ & 3 \\
\hline AN S 352 & $\begin{array}{l}\text { Genetic Improvement of } \\
\text { Domestic Animals }\end{array}$ & 3 \\
\hline \multicolumn{3}{|c|}{ Expertise Expansion (3 Credits) } \\
\hline AGRON 280 & $\begin{array}{l}\text { Crop Development, } \\
\text { Production, and } \\
\text { Management }\end{array}$ & 3 \\
\hline AGRON 334 & $\begin{array}{l}\text { Forage Crop } \\
\text { Management }\end{array}$ & 3 \\
\hline AN S 333 & $\begin{array}{l}\text { Embryo Transfer and } \\
\text { Related Technologies }\end{array}$ & 3 \\
\hline AN S 336 & $\begin{array}{l}\text { Domestic Animal } \\
\text { Behavior and Well-Being }\end{array}$ & 3 \\
\hline AN S 345 & $\begin{array}{l}\text { Growth and } \\
\text { Development of } \\
\text { Domestic Animals }\end{array}$ & 3 \\
\hline AN S 360 & Fresh Meats & 3 \\
\hline TSM 327 & $\begin{array}{l}\text { Animal Production } \\
\text { Systems }\end{array}$ & 3 \\
\hline TSM 455 & $\begin{array}{l}\text { Feed Processing and } \\
\text { Technology }\end{array}$ & 3 \\
\hline TSM 457 & $\begin{array}{l}\text { Feed Safety, Ingredient } \\
\text { Quality, and Analytics }\end{array}$ & 3 \\
\hline VDPAM 487 & $\begin{array}{l}\text { Livestock Disease } \\
\text { Prevention }\end{array}$ & 3 \\
\hline \multicolumn{3}{|c|}{ Enterprise Management (3 credits) } \\
\hline AGEDS 451 & Agricultural Law & 3 \\
\hline ECON 230 & $\begin{array}{l}\text { Farm Business } \\
\text { Management }\end{array}$ & 3 \\
\hline ECON 235 & $\begin{array}{l}\text { Introduction to } \\
\text { Agricultural Markets }\end{array}$ & 3 \\
\hline ECON 332 & Cooperatives & 3 \\
\hline ECON 334 & $\begin{array}{l}\text { Entrepreneurship in } \\
\text { Agriculture }\end{array}$ & 3 \\
\hline \multicolumn{3}{|c|}{ Beef Cattle Production (6 credits) } \\
\hline AN S 426 & $\begin{array}{l}\text { Beef Cattle Systems } \\
\text { Management }\end{array}$ & 3 \\
\hline ANS 399 & $\begin{array}{l}\text { Beef Internship } \\
\text { Experience }\end{array}$ & 3 \\
\hline
\end{tabular}

